\title{
The Classical and Jesuit Erudition of Stefan Iavorskii in His Panegyrics to Varlaam Iasinskii*
}

\author{
Bartosz Awianowicz \\ Nicolaus Copernicus University, Faculty of Humanities, \\ 3, Fosa Staromiejska, Toruń, 87-100, Poland; bartosz.awianowicz@uni.torun.pl
}

For citation: Awianowicz B. The Classical and Jesuit Erudition of Stefan Iavorskii in His Panegyrics to Varlaam Iasinskii. Philologia Classica 2020, 15 (2), 246-260.

https://doi.org/10.21638/spbu20.2020.205

This article offers an overview of the Greco-Latin and early modern Jesuit sources of Stefan Iavorskii's (1658-1722) three bilingual panegyrics addressed to his patron Varlaam Iasinskii, rector of the Kiev-Mohyla college (1669-1689), the Orthodox metropolitan of Kiev (16901707), Hercules post Atlantem infracto virtutum robore honorarium pondus sustinens published in Chernihiv in 1684, Arctos Caeli Rossiaci in Gentilitiis Syderibus and Petnia nieubywaiacey chwały w herbowym xiężycu (The Plenitude of Inexhaustible Glory in the heraldic moon), published in Kiev in 1690 and 1691. Both these works are prosimetric bilinguals (some sections are in Latin, others in Polish), testifying to a significant classical erudition of their author. However, Hercules is one most traditionally "classical" in its dispositio and elocutio, while the style of the other two, written after Iavorskii's educational journey through Jesuit schools in the Polish-Lithuanian Commonwealth, is much more innovative, highly metaphorical, allegorical, relying on the argumentation of surprise (based on acumen- and argutia-theory expounded in the rhetoric of Jan Kwiatkiwiecz) and emblems due to an extensive use of combinations of multiple pictorial-verbal themes (especially in Petnia).

Keywords: Stefan Iavorskii, Varlaam Iasinskii, Neo-Latin Panegyrics, Ancient Roman Poetry, Progymnasmata, Early Modern Rhetoric, Jesuit Rhetoric, Emblematics.

\section{Introduction}

Stefan Iavorskii was born Symeon ${ }^{1}$ Ivanovich in the village of Javora (Ukr. Явора) on the Stryj River ${ }^{2}$ in 1658. After the Truce of Andrusovo (1667), his family moved to the Russian territory, and Iavorskii began his education in Mohyla College in Kiev around 1673. Kiev had come under Russian rule by 1667 , but the school programme still imitated that of the Jesuit Ratio studiorum based on Polish-Lithuanian curriculum in which all subjects, divided into studia inferiora (grammar, syntax, poetics, rhetoric) and superiora (philosophy and theology), were taught in Latin. The poetics was taught also in Polish, and stylistic exercises were practiced in three languages: Latin, Polish and Old Church

* This paper was written as part of research project funded by the National Science Centre (NCN) 2017/25/B/HS2/00932. I am grateful to Cinthia Gannet, John Brereton and Tim Brombley for reading and correcting this article, as well as to the anonymous reviewers and editors of Philologia Classica for their valuable suggestions and criticism.

1 "Stefan" was his monastic name.

2 On the place of Iavorskii’s birth see Kroll 2018, 199. (He also reports earlier literature on this topic.)

(C) St. Petersburg State University, 2020 
Slavonic. ${ }^{3}$ Rectors, professors and prominent alumni of the Kiev-Mohyla college such as Lazar Baranovych, Varlaam Iasinskii or Symeon of Polotsk used Polish and Latin even in their private correspondence. ${ }^{4}$ Iasinskii, rector of the collegium from 1669 to 1689 , became mentor to the young Iavorskii, and one of his most important patrons. Iasinskii, who himself had studied in the Protestant gymnasium in Elbląg (Germ. Elbing) in Polish (Royal) Prussia and in the Catholic universities in Olomouc and Cracow (where he obtained a degree in philosophy), sent his protégé in 1684 to the Polish-Lithuanian Commonwealth to perfect his skills in Latin and Polish, as well as in the poetics, rhetoric, philosophy and theology. Iavorskii studied in Jesuit colleges in Lviv, Lublin and Poznań and at the University in Vilnius as a Roman Catholic. ${ }^{5}$ In 1689 he returned to Kiev and to the Orthodox Church, entering the Kiev Pechersk Lavra monastery. In 1690 Iavorskii, still supported by Iasinskii, ${ }^{6}$ became professor of rhetoric at the Mohyla college, in 1691 professor of philosophy and finally, in 1693, professor of theology. ${ }^{7}$ In 1697 he became hegumen of the Holy Nikolsky Monastery and prefect of its collegium. In 1700 Iavorskii visited Moscow, where his excellent eloquence drew attention of Peter I, and thanks to the tsar's support he was appointed archbishop of Ryazan and, after the death of Adrian, patriarch of Moscow (16 October 1700), locum tenens of the patriarchal see in the capital of Russia. ${ }^{8}$ At the beginning of the $18^{\text {th }}$ century, he supported the tsar in reforming the Orthodox church and was very active as a preacher. However, Iavorskii gradually began to oppose that reform and, as a result, in 1712, Peter I forbade him from preaching in public. Afterwards, Iavorskii wrote his opus magnum, Камень веры (The Rock of Faith), which was rejected by the tsar and published only posthumously in 1728 (the patriarch died on 24 November $1722^{9}$ ).

However, Iavorskii is not only the author of theological writings, but also of the Polish panegyric dedicated to Ivan Mazepa Echo głosu wołajacego na puszczy od serdecznej refleksji pochodzace (The Echo of a Voice of One Calling in the Wilderness, Coming from Heartfelt Reflection) published in Kiev in 1689, and three panegyrics about his patron Varlaam Iasinskii, rector of the Kiev-Mohyla college (1669-1689) and Orthodox metropolitan of Kiev (1690-1707): Hercules post Atlantem infracto virtutum robore honorarium pondus sustinens (Hercules carrying the honorable burden after Atlas, thanks to the adamant strength of virtues) published in Chernihiv in 1684, Arctos caeli Rossiaci in gentilitiis

${ }^{3}$ See Kroll 2018, 200-201; Niedźwiedź 2018, 452-453 and especially Łużny 1966, 9-107.

4 See Łużny 1966, 13-15.

${ }^{5}$ Under the changed name "Stanisław" because, at that time, in order to study in Jesuit schools it was necessary to convert to Catholicism (or, at least, become a member of the Uniate church). Many converts, along with their confession, changed their names to ones more associated with the Catholic tradition. See Kroll 2018, 204, and Treadgold 1973, 61.

${ }^{6}$ On the still great authority and importance of Iasinskii among his former students, see Dimitry Tuptalo's (metropolitan Dimitry of Rostov) letter to Iavorskii from Frebruary 24, 1708: “Він пригадував ті гарні часи, коли вистачало прочитання твору Варлаамом Ясинським, щоб упевнитись, чи він вартий друку, - а тоді й сам друк відбувався без перешкод (“Мнъ преосвященство ваше unus pro mille. Такъ бывало и блаженныя памяти [...] нашъ Варлаамъ [...], что он прочитает и не зганит, то несумнънно до друку подавалося")" (Fedotova 2005, 141-142).

7 See Nikolaev 1995, 117.

8 Giovanna Brogi Bercoff emphasizes that Iavorskii never wrote panegyrics in Russia, because Peter preferred other panegyrists and the patriarch "could not have had the same feeling" for the tsar court as earlier for Iasinskii’s or Mazepa’s court. See Brogi Bercoff, 61-62.

9 For Iavorskii's biography see Zakhara 1991. Last 22 years of the patriarch are described in detail by Ternovskiy 1879 and Morosov 1971. See also Brogi Bercoff 2013a, 259-266 and 2013b, 509-511. 
syderibus (Arctos of the Russian sky in the ancestral stars) published in Kiev in 1690, and Petnia nieubywaiacey chwaty w herbowym xiężcu (The Plenitude of inexhaustible glory in the heraldic moon) issued by the same publisher in the following year. All works dedicated to Iasinskii are prosimetric and bilingual, written in Latin and Polish, revealing a substantial erudition of the author.

\section{Hercules post Atlantem as a Fruit of Iavorskii's Classical Education in the Kiev-Mohyla Colledge}

A combination of prosaic, poetic and even emblematic parts was quite common in early-modern Western and Central European panegyrics, including texts written in the Latin and Polish language in the Polish-Lithuanian Commonwealth. ${ }^{10}$ A good example here is provided by Applausus, quos in desideratissimum Poloniae et Sueciae Principem, Serenissimum Vladislaum Sigismundum (...) pleno debitae observantiae ac devotionis animo effundit nobilis iuventus Collegii Luceoriensis Societatis Iesu, anno MDXVII (printed in Cracow in 1617, after 6th August) where Jesuits and their students from the Lutsk college praised prince Ladislaus in Latin prose orations, odes, emblematic epigrams and inscriptions. ${ }^{11}$ However, the combination of Latin and Polish texts in almost equal parts in one panegyric written by one author seems to be a hallmark of Iavorskii's epideictic style, as well as a result of education in the Kiev-Mohyla Collegium. Ryszard Łużny observes that in the humaniora classes (that is, poetics and rhetoric) in the college, students were taught both in Latin and in Polish ${ }^{12}$ and, as Giovanna Siedina remarks, during the poetics course they "were exposed to writings of Latin authors such as Ovid, Sallust, Seneca, Claudian, Martial, Vergil, Horace and others, as well as contemporary Neo-Latin authors and outstanding Polish writers of the Renaissance and Baroque such as Jan Kochanowski, Samuel Twardowski and Maciej Kazimierz Sarbiewski". ${ }^{13}$ While poems by Sarbiewski (Sarbievius), who wrote only in Latin, were treated as models on an equal footing with ancient Roman authors, Kochanowski and Twardowski read for their works written in Polish.

Because Hercules post Atlantem is the only one of Iavorskii's work published before Stefan went to study in Jesuit schools, and therefore the fruit of his Kiev education, it is worthwhile to compare the rhetorical structure and use of ancient and Neo-Latin sources in this early panegyric with Arctos caeli Rossiaci and The Plenitude of inexhaustible glory, which were written after author's return to Kiev.

Hercules post Atlantem is a 38-page booklet in folio with the title, motto and 24 pages in Latin and 12 pages in Polish (with a short Latin ending). The longest Latin part (14 pages) begins with the apostrophe to Iasinskii as newly-elected archimandrite of the monastery Kiev Pechersk Lavra. Next, Iavorskii introduces his main metaphor in which Iasinskii's predecessor in this position, Innocent (Innokentiy) Gizel (c. 1600-1683), is called Atlas and Iasinskii himself - Hercules. Shortly aferwards, he compares the late archimandrite with Castor and the new one with Pollux. These two metaphors serve here to express

10 See for example Niedźwiedź 2003, 185-249.

11 See https://polona.pl/item/applavsvs-quos-in-desideratissimum-poloniae-et-sueciae-principemwladislavm,NDc2MDQ4NjA/ (accessed: 26.02.2020).

12 See Łużny 1966, 10-11.

13 Siedina 2017, 7-8. 
Iasinskii's superiority over his predecessor. In the rest of the Latin test, however, Iavorskii focuses on Iasinskii's wisdom (sapientia) as first and the most important strength to deliver in his new honorable office (p. a 2 rectro: primum [...] robur in honorario pondere sustinendo) and praises his talent, erudition and other intellectual virtues in chronological order: first, during his studies in Kiev and at the Cracow Academy (a 2 verso - B recto), after that, during his rectorship at the Mohyla College (p. B 2 recto - verso). Finally, he emphasizes that the new archimandrite has gained recognition also in Moscow as an excellent orator and theologian (C 2 recto - verso). Afterwards, Iavorskii praises Iasinskii's "pious humbleness" (humilitas religiosa), then his strength (robur), and finally generosity (liberaritas). ${ }^{14}$ Three Polish strophic poems written in alexandrine verse, placed directly after the praise of Iasinskii's sapientia, humilitas religiosa and liberalitas, amplify on these three virtues.

Both Latin and Polish parts of the panegyric are based on rules of classical rhetoric, especially on the theory of encomium in Aphthonius' Progymnasmata. This Greek

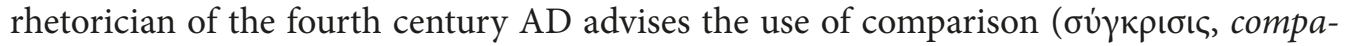
ratio) to amplify the superiority of the praised person or thing over the other person or thing. ${ }^{15}$ So Iavorskii begins with placing Iasinskii as Hercules and Pollux over Gizel as Atlas and Castor. Furthermore, Aphthonius gives an exemplary encomium of wisdom

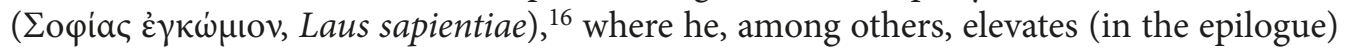
wisdom over courage (ả $\delta \rho \varepsilon \dot{\alpha}$, fortitudo). Similarly, wise Iasinskii as "victor of minds" (C recto: mentium victor, animorum triumphator) surpasses those who triumphed because of bloodshed. Aphthonius' handbook was read in the majority of humanistic schools in $17^{\text {th }}$-century Europe, ${ }^{17}$ including the Polish-Lithuanian Commonwealth and Polish Prussia $^{18}$ where Iasinskii had studied before becoming Iavorskii's professor at the Kiev-Mohyla college. Therefore, it seems very likely that the young Iavorskii knew Progymnasmata and followed the progymnasmatic pattern of encomium.

In other places Apthonius recommends strengthening the argumentation of an anecdote ( $\chi \rho \varepsilon i a$, chreia) and maxim ( $\gamma \nu \omega \dot{\mu \eta}$, sententia) with "testimonies from the ancients"

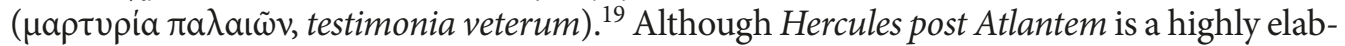
orate panegyric, not a school exercise, we can still recognize here Iasinskii's need to amplify it with citations from ancient authors which serve him as testimonia veterum of his patron's virtues. At the beginning of the chapter about wisdom as particular virtue (a 2 v.), Iavorskii quotes a sententious verse from Horace's Odes 3.4 (v. 65) as a general maxim:

Vis consilii expers, mole ruet sua.

"Brute force bereft of wisdom falls to ruin by its own weight" 20

14 See Hercules post Atlantem 23-27 and 33-35.

15 See Aphthonius, Prog. VIII 3 (Patillon 2008, 132) and [Aphthonius] 1640, 230.

16 See Apthonius, Prog. VIII 10-15 (Patillon 2008, 134-137) and [Aphthonius] 1640, 234-236.

17 It had from $15^{\text {th }}$ to $18^{\text {th }}$ century several translations into Latin and only in the most popular contaminated translation by Rudolphus Agricola and Johannes Maria Catanaeus with scholia by Reinhar Lorich has been published about 150 times from its first edition in 1542 to the year 1718. See Awianowicz 2008, 107-108 and 227-234 and 2011, passim and Kraus 2005, 167-183.

18 Cf. Awianowicz 2008, 272-273 and 308-310. Aphthonius' handbook in Agricola's and Catanaeus' translation was published among others in Gdańsk in 1636: https://polona.pl/item/aphthonii-sophistaeprogymnasmata,MTA2MDY2MDM1/4/info:metadata (accessed: 10.05.2020).

19 See Apthonius, Prog. III 3 and IV 3 (Patillon 2008, 115 and 118); Aphthonius 1640, 53 and 105.

20 Translated by Bennett 1968 . 
This is the only place, where the Ruthenian author doesn't add the poet's name in the margin. However, he could well have omitted it because the sentence was treated in $17^{\text {th }}$-century Europe as common good. ${ }^{21}$ Two other quotations from Horace $(O d .2 .10 .9-$ 12 and 3.16.10-11) appear (with references "Horatius" and "Horat.") in parts of the panegyric praising Iasinskii’s "pious humbleness" (humilitas religiosa - p. [25]) and his generosity (liberalitas) and munificence (munificentia - p. [34]):

$$
\begin{aligned}
& \text { Ocius }^{22} \text { ventis angitatur ingens } \\
& \text { pinus et celsae graviore casu } \\
& \text { decidunt turres feriun }<\mathrm{t}>\text { que summos } \\
& \quad \text { flumina montes. }
\end{aligned}
$$

"Tis oftener the tall pine that is shaken by the wind; 'tis the lofty towers that fall with the heavier crash, and 'tis the tops of the mountains that the lightning strikes."23

And about gold (aurum):

quod perrumpere amat saxa potentius

ictu fulmineo

"which loves to break through rocks stronger than the thunderbolt". 24

The first quote is an element of argumentum ex contrario in which Iavorskii opposes humilitas of his patron to personified arrogance (superba frons) always exposed to destruction (pernicies) and rapid fall (praecipiti casui obnoxia ${ }^{25}$ ). The second serves to amplify the metaphorical picture of "live marbles" (vivi marmores) and "giant stone statues" (Memnonii lapides) of Iasinskii's munificentia.

Also three quotations from Claudian in Hercules post Atlantem (p. a2 verso, B recto and B2 verso) have an amplifying argumentative function. Iavorskii quotes In Rufinum (Pan. I 22-23) by the poet of the late Roman Empire, a slightly changed and shortened beginning of his Fl(avii) Mallii Theodori panegyris (Pan. XVII 1-3) ${ }^{26}$ and a passage from De raptu Proserpinae (1.157-159), also shortened, with some alterations and without the

${ }^{21}$ Cf. for example a pièce satirique: https://gallica.bnf.fr/ark:/12148/btv1b84010649/f1.item.zoom (accessed: 26.02.2020).

${ }^{22}$ Instead of saepius as in most editions. See for instance Horace's editions by Denis Lambin popular in $16^{\text {th }}-17^{\text {th }}$ centuries (Lambin 1584, 49), Jan Minell and Friedrich Rappolt (Minell, Rappolt 1675, 160) and Jesuit "Horatius Flaccus ab omni obscoenitate Romae expurgatus" (Horatius expurgatus 1613, 48 and 1652, 42). Some modern editors accept the conjecture saevius instead of saepius (see Shackleton Bailey 1985, app. ad loc.).

${ }^{23}$ Od. 2.10.9-12 3.16.10-11 translated by Bennett 1968.

${ }^{24}$ Cf. Hor. Od. 3.16.9-11: aurum per medios ire satellites / et perrumpere amat saxa, potentius / ictu fulmineo (Gold loves to make its way through the midst of sentinels and to break through rocks, for 'tis mightier than the thunderbolt - translation by Bennett 1968).

${ }^{25}$ The use of this adj. obnoxia shortly before the quote from Hor. Od. 2.10 .9 can be the reason for the replacement of saepius by ocius, to create an alliteration.

26 See Hercules post Atlantem: B recto:

Ipsa sibi virtus pretium, nec Laudibus ullis

Erigitur plausuque petit clarescere vulgi.

"Virtue is its own reward; no praises raise it higher nor does it seek glory from the mob's applause" (transl. from Claudian, with some alterations by Platnauer 1922). 
author's name in the margin, ${ }^{27}$ which serve here to strengthen the literary picture in which Iavorskii describes how Ianovski as Hercules metaphorically defeats the giant Enceladus (B2 verso), who:

$$
\begin{aligned}
& \text { quoties retrectat }{ }^{28} \text { onus cervice rebelli } \\
& \text {...tunc Insula fundo } \\
& \text { vertitur et dubiae nutant cum moenibus urbes. }
\end{aligned}
$$

"Whene' er his rebellious shoulders shift their burden, the island is shaken from its foundations and the walls of tottering cities sway this way and that."

Claudius Claudianus seems to be one of those Roman writers who were particularly important to Iavorskii. He possessed a volume in octavo with works by the Roman poet. ${ }^{29}$ In addition, the book by the author of De raptu Proserpinae is one of the very few Latin poetical works recorded in the catalogue of Iavorskii's library.

Another famous Roman poet mentioned by name twice in the margin of Hercules (B r. and C r.) is Ovid, once called also vates - "the prophet" (C2 v.). Iavorskii quotes verses from Tristia (1.5.25) and twice from Metamorphoses. The first citation (Met. 1.109) illustrates the golden age in the Kiev Pechersk Lavra monastery under Iasinskii as an archimandrite (after 1684), the second (Met. 2.54-55: non viribus istis / munera conveniunt) is included in the amplification of the Iasinskii's wisdom which even mythical Geryons and Typhons cannot subdue.

Indeed, the quotes from Roman writers (especially poets) woven into Iavorskii's text are not the only evidence of his classical erudition. The very idea of calling Iasinskii "Hercules" and comparing his career and deeds with those of the mythical hero has a good humanistic provenance. There are many panegyrics dedicated to early modern kings, princes and generals praised as new "Herculeses" 30 , but the identification of rulers with the mythical hero has a tradition dating back to Alexander the Great. ${ }^{31}$ Examples we can mention here include only the texts published shortly before Iavorskii's Hercules, such as: Columnae triumphales ad quas fortis olim Hercules Magnanimus ac Generosus Dominus, D(ominus) Stanislaus Piotrkowczyk, tribunus militum Sac(rae) Reg(is) Maiestatis Metam Imortalitatis post bellica trophaea attingens constitit by J. B. (Cracow 1675), and Hercules Prodicius seu Carolus Juliae, Cliviae ac Montium Princeps in Joanne Wilhelmo Comite Palatino Rheni Nepote post saeculum redivivus by the Jesuit Joannes Pakenius (Cologne 1679). Even the bold concept of using the metaphor of Hercules in reference to the scholar and theologian is not entirely new. For example, a panegyric in Latin elegiac couplets entitled

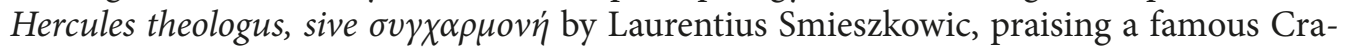
covian Catholic scholar Marcin Kępka (1567-1641) — also known as "Wadowita” — was published in Cracow in 1617.

${ }^{27}$ Iavorskii used to quote from memory and shorten even passages from the Bible. See for instance Latin citations in his sermon Commoda mansio in Monte Thabor from 1694 (MS sig. РГИА. Ф. 834. Оп. 2. Д. 1592): 150 verso (Eccl. 9: 12) and 151 verso (1 Cor. 10).

${ }^{28}$ Instead of detrectat as in most editions of Claudian's works published in the $16^{\text {th }}$ and $17^{\text {th }}$ centuries. See for instance Polemann 1571, 23; Crinitus 1598, 25 and Poelmann, Delrío 1612, 20.

29 Maslov 1914, 52 (574.111). Unfortunately, the catalogue, written by Iavorskii himself, very seldom informs us what editions he possessed. In the case of Claudian, only the title "Claudianus" is given.

${ }^{30}$ Among others Cosimo de Medici and Gustavus Adolphus.

31 See Demandt 2004. 
Hercules post Atlantem is deeply rooted in the older, more ancient and humanistic tradition. On the one hand, the disposition of his panegyric is based on the progymnasmatic model and many of his metaphors in Latin parts are variations based on commonly known Roman authors Horace, Ovid and Claudian, and in the Polish from Jan Kochanowski in particular; ${ }^{32}$ on the other, he already knew Ars nova argutiarum by German Jesuit Jacob Masen, whom he mentions (C 2 verso, on the margin) as the author of the elegiac verses:

hi mihi doctores semper placuere, docenda

qui faciunt plus, quam qui facienda docent

"I have always preferred those teachers who do what they teach, than those who teach what to do."33

Masen is an important representative of the argutia-movement, one of main currents of $17^{\text {th }}$-century (mostly Jesuit) rhetoric, ${ }^{34}$ but Iavorskii, before his studies in Polish Jesuit schools, adopted only the concept of argutia as a simple verbal ornament ${ }^{35}$ and the idea of bilingualism characteristic of much Polish-Lithuanian epideictic literature.

\section{Arctos caeli Rossiaci and Pelnia nieubywaiacey chwaly as reception of Jesuit acumen and emblematics}

As Jakub Niedźwiedź observes, "in the first half of the seventeenth century, the Jesuit model of education became a standard, even in non-Catholic schools, throughout the entire Polish-Lithuanian Commonwealth" ${ }^{36}$ However, the second half of the $17^{\text {th }}$ century was also, as Janusz Pelc argues, the climax of the development of Polish emblematics, and Jesuit colleges excelled in their popularisation and propagation, so emblems based on Dutch and Jesuit Italian, German and Spanish models, as well as a new type originating in Polish literary and heraldic tradition, were present not only in poetry, prose panegyrics and sermons, but also in academic theses and disputations. ${ }^{37}$ Therefore, it is worth asking here how Iavorskii's studies in the Polish-Lithuanian Commonwealth influenced all three officia oratoris: inventio, dispositio and elocutio in his two panegyrics written shortly after his return to Kiev: Arctos caeli Rossiaci from 1690 and Petnia nieubywaiacey chwaty (The Plenitude of inexhaustible glory) from 1691.

If we consider just the titles themselves, we will find that they are more original and conceptual. The noun Arctos is attested in at least two titles of works published before Iavorskii's work: Arctos Sarmatica, quae Generosae Iuventuti Academicae primam in artibus et philosophia lauream in Aula Divi Iagelonis, containing Latin poems by many alumni of the Cracow University and published in $1638,{ }^{38}$ and Arctos respirans auspiciis Sanctissimi

${ }^{32}$ In particular from Treny (Laments) I, IV and X by the Polish Renaissance poet. However, Iavorskii never quotes from Kochanowski directly; he always paraphrases him.

${ }^{33}$ Masen 1660, 41. In fact, it is a distich (first half of Epigr. II 24) by Welsh poet John Owen (c. $1564-$ c. $1622 / 1628)$.

34 Kapp 1992, 993-994.

35 Cf. Sarbiewski 1958, 30 and Siedina 2014, 121, note 32.

36 Niedźwiedź 2018, 453. Cf. Grendler 2019, 43-45 and Jabłonowski 1899-1900, 97-102.

37 Pelc 2002, 235-350.

38 See https://polona.pl/item/arctos-sarmatica-qvae-generosae-ivventvti-academicae-primam-in-artibus-philosophia,ODg4MzExNjI/2/ info:metadata (accessed: 26.02.2020). 
et Augustissimi Regis Christiani Quinti, Daniae, Norwegiae, Vandalorum, Gothorumque Haereditarii Monarchae, Domini Pietate et Justitia florentissimi - a poem in Latin hexameters by Olaus Borrichius and published in Copenhagen in $1671 .{ }^{39}$ For the Polish title Petnia nieubywaiacej chwały... we can give only one analogy dated earlier than the Kiev print; it is a Polish-Latin macaronic panegyric Pelnia w ostatniey kwadrze na polskim horyzynocie by Krzysztof of Zegotki Zegocki, published in $1672 .{ }^{40}$

If we look at the composition of Arctos caeli Rossiaci and Petnia nieubywajacey chwały, we will find that these bilingual panegyrics of 40 (Arctos) and 48 pages (Petnia) in folio display a more developed and varied form, with more hidden literary sources in them. Both texts seem to be composed according to rules of "extraordinary eloquence" (eloquentia non vulgaris) by Polish Jesuit Jan Kwiatkiewicz (1630-1703), professor of rhetoric, ethic and theology in Lviv, Lublin, Kalisz and Jarosław, as well as rector of colleges in Sandomierz and Jarosław. Kwiatkiewicz in his Phoenix rhetorum, a popular handbook printed at least 11 times between 1672 and 1720 in Cracow, Cologne, Kalisz, Prague and Wrocław, ${ }^{41}$ argues that such an extraordinary work of rhetoric should contain the following "fundamental elements" (fundamenta):

1. sensus admirabiles ("admirable (or paradoxical) observations")

2. eruditionis usus non vulgaris ("extraordinary use of erudition")

3. mirum acumen ("surprising acumen")

4. descriptiones admirabiles ("admirable descriptions")

5. affectus non vulgares ("extraordinary affections")

6. mira per allegoriam et insigniores figuras styli exornatio ("surprising ornamentation based on allegories and eminent figures of style")

7. circumstantiarum rerumque mira combinatio ("surprising combination of circumstances and things")

8. amplificationis usus singularis ("unique use of amplification")

9. Argumenti tractandi varia, nec obvia ratio ("diverse and not obvious way of argumentation")

10. numerus oratorius et admirabile decorum ("rhetorical period and admirable seemliness"). ${ }^{42}$

In Arctos, written for the appointment of Iasinskii as metropolitan of Kiev, we can identify quotations or paraphrases from Latin poets: Lucretius (6.635-637), Ovid (Epist. 12.38, Met. 4.64, Rem. 43-44, Met. 2.295-296, 1.168-170 and 15.871-874), Claudian (6 verses from Deprecatio ad Hadrianum, 22.35-40), German Jesuit Jacobus Pontanus ${ }^{43}$ and Polish Jesuit Maciej Kazimierz Sarbiewski (Lyricorum libellus I, 2.2-3), as well as from prose writers: Cicero (Tusc. 5.51), Pliny the Elder (NH 34.19.23) and Seneca the Younger (Dial. 7.17.2). ${ }^{44}$ Although Iavorskii still prefers poetical works, especially those by Ovid,

39 https://reader.digitale-sammlungen.de//resolve/display/bsb11324220.html (accessed: 26.02.2020).

40 See https://polona.pl/item/pelnia-w-ostatniey-kwadrze-na-polskim-horyzoncie-gryzelda-constancya-xiezna-na,Njc1ODAzMDM/4/ info:metadata (accessed: 26.02.2020).

${ }^{41}$ See Słomak 2016, 59-60.

42 Kwiatkiewicz 1690, 6.

43 Iavorskii travesties his hexameter "you see great rivers flowing from small streams" (Flumina magna vides parvis de fontibus orta) - see Pontanus 1610, 1202.

${ }^{44}$ See Arctos, A v. (Lucretius), A2 r. (Pontanus), A2 v. (Seneca), D v. (Cicero), D2 r. (Ovid twice), D2 v. (Sarbiewski and Claudian), E 2 v., H v., H 2 r. and [K] v. (Ovid). 
who is quoted six times, the paraphrases from Seneca and Pliny are particularly interesting here, because they confirm the departure from Ciceronian canon according to Kwiatkiewicz's advice that the "admirable" orator should diversify his style and "speak at times like Tullius, at times like Pliny, like Seneca or Puteanus or other brilliant speakers". ${ }^{45} \mathrm{We}$ can add here that Iavorskii possessed in his library Lyricorum libri 4 by Sarbiewski, ${ }^{46} \mathrm{Op}$ era omnia by the author of Epistulae ad Lucillum, Senecae philosophi de rebus naturalibus et epistolae ${ }^{47}$ and Naturalis historia in large (in folio) format, ${ }^{48}$ but also Phoenix rhetorum by the Polish Jesuit. ${ }^{49}$

Kwiatkiewicz recommends the introduction of an acumen based on the coat of arms (ex stemmate acumen $)^{50}$ and refers to his earlier work Svada civilis, where he discusses praises derived from such emblems as: crescent (luna), arrow (sagitta) and stars (stellae) ${ }^{51}$. He describes the stars as symbols of both virtue (virtus) and good fortune (fortuna), and advises, among other possibilities, that arrows be presented as symbols of "a quick pursuance of virtue" (celeres ad virtutem impetus). We recognize very similar elements in the epigram placed below the Iasinskii's coat of arms $\left(\mathrm{Sas}^{52}\right)$, where Iavorskii claims that his patron "possesses his own Olympus among his stars" (v. 1: Syderibus, vir summe, Tuis est patria Olympus), his "long arrow willingly goes there" (v. 3: quid, quod et alta sagitta illuc quoque cuspide tendit?) and "the fame lifts him to the stars" (v. 6: quid mirum quod Te fama per astra ferat?). Next, Iavorskii elaborates the metaphorical description of the coat of arms especially in the part of his panegyricus entitled "Arctos of the ancestor constellations of the Most Honorable Metropolitan" ( $\mathrm{H}$ recto $-\mathrm{H} 2$ verso: Arctos avitorum Illustrissimi Archipastoris syderum), among others, expanding on the Kwiatkiewicz's "new and marvellous metaphor, where the Moon turns into the Sun". ${ }^{53}$

Furthermore, the composition of Arctos, both its Latin and Polish parts, is subordinated to Latin emblematic inscriptiones or lemmata, referred to by Iavorskii as "epigraph" (epigraphe):

- Immobilis ad immobile lumen (B) - "immobile to immobile light",

- Lucet et accendit (C recto) - "shines and ignites",

- Nil indiga lucis (D recto) - "Needs no light",

- Inoccidua sequor (E recto) - "I follow what does not descend",

- His secura polis (F recto) - "Safe under this sky",

- Hac cardine tutus (H recto) - "Secure thanks the pole"

- Vertitur, non occidit (J recto) - "Sinks, not disappears"

${ }^{45}$ Kwiatkiewicz 1690, 289: "nunc ut loquitur Tullius, nunc ut Plinius, nunc ut Seneca vel Puteanus et alia eloquentum lumina."

46 Maslov 1914, 52 (587.124).

47 Ibid. 29 (180.22) and 50 (531.68).

48 Ibid. 39 (266.27).

49 Ibid. 51 (562.99).

50 Kwiatkiewicz 1690, 90-92.

51 Kwiatkiewicz [1679?], 62-64 and 70-73.

52 A Central and Eastern European coat of arms of several Transylvanian-Saxon, Hungarian, PolishLuthuanian, Ruthenian and Ukrainian noble families.

${ }^{53}$ Kwiatkiewicz [1679?], 62: "[in] nova et prodigiosa metamorphosi, ubi Luna in Solem plane immutatur". Cf. for instance the exclamatice sentence (Arctos, H 2 vero): "O prognosticam tantae felicitatis Lunam, jam non Lunam, sed Solem meritissimum, nisi Lunam inde, quod per continua luminum crescat incrementa!" 
The first lemma seems to be a turn on Diego de Saavedra Fajardo's Symbolum XXIV with the motto Immobilis ad immobile numen describing a prince who protects religion (religio) as the soul of countries (anima rerumpublicarum). ${ }^{54}$ Another emblem of the Spanish author, Symbolum LXVIII (His polis) ${ }^{55}$ seems to be an inspiration for the fifth Iavorski's epigraph. We can also indicate Mondo simbolico formato d'imprese scelte, spiegate ed illustrate con sentenze, ed eruditioni, Sacre, e Profane..., a popular encyclopaedia of emblems by Filippo Picinelli, published also several times in Latin, ${ }^{56}$ as a possible source of three of the five above-listed epigraphs. Lucet et accendit is based on the lemma Lucet et ardet, described there as one emblems derived from the Bible (emblemata S. Scripturae). ${ }^{57}$ Other two are a kind of puzzle that Picinelli solves: that what "needs no light" is "an owl" (noctua), and the sentence "I follow what does not descend" describes, according to Mondo simbolico, "calamity". ${ }^{58}$ The answer calamitas doesn't match the obviously encomiastic goal of the panegyric, but placing the sentence in a new, encomiastic context is consistent with Kwiatkiewicz's advice that really admirable ideas and observations should be new and cannot be commonly used (supra vulgares emineant). ${ }^{59}$ Only Hac cardine tutus seems to be a completely new motto referring to the Moon from Iasinskii's coat of arms. ${ }^{60}$

Highly recommended are also paradoxical sentences, for instance the following sentence about a great orator: "he is the most eloquent, even when he is silent", ${ }^{61}$ which resembles Iavorskii's idea of praising Iasinskii's modesty "more like Harpocrates ${ }^{62}$ than Tullius" (A 2 recto: Harpocrati similior quam Tullio), repeated also in the form "more like silent Harpocrates than a panegyrist" (F 2 recto: "silentio Harpocrati similior quam panegyristae").

In an elaborate poem that follows the first epigraph, Echo describes Iasinskii's election to metropolitan as the will of heaven (B recto: Polis certe placuit) and Iasinskii himself as a sage (B verso: sophus) and man of virtue, honour and modesty (B verso - B2 verso: virtus, honor and modestia), so we can interpret the "lemma" as a philosophical reference to the immobile God and immobile stoic sage, whose virtus et actio, as Marsilio Ficino claims, is immobilis and as such corresponds with divinity (congruit cum divinis). ${ }^{63}$ In the part elaborating the epigraph Nil indiga lucis, Iavorskii refers the sentence to the Attic

54 Saavedra Fajardo 1660, 190-196.

55 Saavedra Fajardo 1660, 576-583.

56 The first complete Latin edition of the work was published in 1681: Philippus Picinello, Mundus symbolicus, in emlematum universitate formatus, explicatus et tam sacris, quam profanis Eruditionibus ac Sententiis illustratus... nunc vero Justo Volumine auctus et in Latinum traductus a R(everenti) D(omino) Augustino Erath..., Coloniae Agrippinae, Sumptibus Hermanni Demem 1687. The first Italian edition had already appeared in 1635 .

57 See Picinelli 1681, c 4 (I.Etymologia et antiquitas symboli) and 69 (Splendet seu lucet et ardet as a "prerogative" of John the Baptist).

58 See Picinelli 1680, Applicationi varie, s.v. According to him, also that what is "immobile to immobile light" is "calamity" (calamitas), but Saavedra Fajardo's Symbolum XXIV seems to suit much better to Iavorskii's text that follows after the epigraph.

59 See Kwiatkiewicz 1690, 16.

${ }^{60}$ Even if it resembles the verse from Leontius von Egg's Oestrium poeticum: "Omnis in Angelico cardine tutus homos" (Golt 1712, 273: "every man secure in the axis of angels").

${ }^{61}$ Kwiatkiewicz 1690, 11: "ille sensus de eximio oratore deducitur: disertissimus etiam dum taceret".

62 Harpocrates who was often represented as an infant with his finger held to his mouth as a sign of silence and economy of words. See Plutarch, De Iside et Osiride 68 and Alciatus, emblem III In silentium.

${ }^{63}$ Ficino 1602, 1027. Cf. Also idem, Libri theologiae de immortalitate animorum, I 6 (Ficino 2001, 78-79). 
owl (D verso), but most of all to Iasinskii who, as a modest Christian scholar, condemns honours, even as high as his new metropolitan post. The author of Arctos encourages Iasinskii to bear "this burden of honourable bonds", as in the panegyric from 1684, calling him "Hercules" (B 2 verso).

The most important innovations in Arctos are not mythological metaphors or lessknown exempla from ancient history. Iavorskii's learning in Jesuit colleges and at universities had a significant impact especially on the argumentation and arrangement of the panegyric, ordered by emblematic epigraphs and inspired by surprising acumina.

Walter Kroll observes that "the selection of imago was the basis of the poetic creative process" 64 in the $17^{\text {th }}$-century Jesuit milieu and the image took priority over the text. Accordingly, the composition of Pelnia nieubywaiacey chwaly is organised both by emblems and by poems dedicated to three Barlaams (Varlaams): the Saint Hermit (known especially from the Byzantine history of Barlaam and Josaphat, king of India ${ }^{65}$ ), the Saint Martyr (from Caesarea in Cappadocia, martyred in the early $4^{\text {th }}$ century) and the Saint of Pechersk (first abbot of the monastery of Kiev Pechersk Lavra in the $11^{\text {th }}$ century). Kroll emphasises that all emblems constructed of groups of imagines represented in Petnia belong to the Western European - and particularly the German - tradition. ${ }^{66}$ The stories of all three saints to whom Iavorskii compares his patron Iasinskii belong to Greek patristic or Orthodox Byzantine and Slavic literature. The story of Barlaam the Hermit and Josaphat is traditionally attributed to Saint John of Damascus (ca. 675-6 - 749); the Byzantine monk and priest Barlaam the Martyr appears several times in Saint Basil's Homilies; ${ }^{67}$ and Barlaam of Pechersk belongs to the local Kiev saints. However, Iavorskii connects Eastern and Western classical tradition when, for example, in Petnia he compares Barlaam the Hermit with several heroes from Greco-Roman mythology and history. The saint is then (D2 recto) "more gorgeous than Cleopatra's Antonius" (Sanctior Hic quam Cleopatreus Antonius), "more dignified than Cineas or Ulysses" (Sacratior Hic Cyneas an Ulysses), "more divine than Pericles" (Hic Divinior Pericles) and "more fortunate than Alcides" (Hic Beatior Alcides). Furthermore, when Iavorskii writes in the encomium of Saint Barlaam the Martyr that "not only Cappadocia has its thaumaturges, Athens has its sages, not only Macedonia Alexanders, not only Laconian women [great] warriors and, finally, not only Assyria phoenixes" (G recto):

\author{
Nec iam sola Cappadocia Thaumaturgos, \\ nec solae Athenae Sapientes, \\ nec sola Macedonia Alexandros, \\ nec solae Lacenae Viros, \\ nec denique sola Assyria Phaenices parturi<i>t.
}

He is thinking not only of the Cappadocian saint, who elsewhere is also called "the most divine Hercules" (H 2 recto: Hercules divinissimus), but also of the Kiev metropolitan

64 Kroll 2018, 234.

65 Translated into Russian as История о Варлааме и Иоасафе and published in 1680 at a press in the Moscow Kremlin.

66 See Kroll 2018, 228-229.

67 See especially PG 31.483-90 (Homilia in Barlaam martyrem). 
Iasinskii who is an heir to the sainted martyr Varlaam - a new Phoenix, but also an owl of the Attic Minerva (G verso: Atticae Minervae Noctua).

These are only a few comparisons, enumerations, metaphors and concepts that serve to amplify Iasinskii's virtues. The accumulation of figures and tropes in Petnia does not help in identifying Iavorskii's sources for this work. We know that he possessed an edition of Opera omnia by John of Damascus in folio, ${ }^{68}$ but he may have found other works useful in writing the panegyric in other Kiev libraries too. It is easier to identify sources of his emblems, because the catalogue of Iavorskii's library confirms his particular interests in that field: he possessed twelve books of emblems and used others from the libraries of his friends and Kiev-Mohyla college. ${ }^{69}$ Walter Kroll, who analyses the pictorial-verbal combinations in Petnia, states that each part of them is "constructed on the basis of graphic patterns present in West European emblem books" and Iavorskii's idea of emblem "approaches Masenius' concept of pictorial-verbal combinations, which the latter presented in his late Baroque work Speculum imaginum Veritatis occultae"70 (Cologne 1681). The German scholar mentions also Herman Hugo's Pia desideria (Antwerp 1624), Silversto Pietrasancta's De symbolis heroicis (Antwerp 1634) and Diego Saavedra Fajardo's Idea principis Christiano-politici, centum symbolis expressa (Bruxelles 1649) as Iavorskii's sources, ${ }^{71}$ and observes that the author of Petnia and his engraver use the technique of creating pictorial-verbal complexes based on the German tradition represented by Franz Julius von dem Knesebeck, Johann Michael Dilherr and Georg Philipp Harsdörfer. ${ }^{72}$

\section{Conclusion}

It follows from the above that Hercules post Atlantem (1684) relies heavily on classical rhetoric and ancient, especially Roman, sources. Iavorskii presents Iasinskii's education and career mostly in chronological order, puts the names of quoted classical authors in the margin to prove his erudite accuracy, calls on less surprising metaphors, makes no use of emblems. The invention and division of Arctos caeli Rossiaci and Petnia nieubywaiacey chwaty, written and published after Iavorskii's return from the Polish-Lithuanian Commonwealth, are already clearly influenced by the acumen-theory, expounded in Kwiatkiewicz's works, and emblematics. But while in Arctos the panegyrist still combines prose and verse, quoting and paraphrasing poetical works by Ovid and Claudian in respect to the previous tradition, Petnia is the most sophisticated of all three encomiastic works, and here Iavorskii boldly mixes literary images taken from classical Greek and Latin, Patristic, Byzantine and early-modern sources. In a metaphorical picture in Hercules, the Polish eagle "prides himself on the newcomer's [i.e. Iasinskii as student and alumnus of the Cracow University] ornaments, not because he wouldn't have his own elegance", but because he recognised Iasinskii as an equal to the Polish professors and writers (B 2 recto: adventi<c $>$ iis in Te gloriaretur ornamentis, non quidem quod suis careret decoribus, verum quod Te parem suis iudicaverit). We could well reiterate these words to apply them to Ia-

68 See Maslov 1914, 40 (296.57).

69 See Kroll 2018, 216-219.

70 Kroll, Stefan Jaworski and emblematics in: http://www.polishemblems.uw.edu.pl/index.php/en/ news-uk/73-stefan-jaworski-and-emblematics (accessed: 26.02.2020) and cf. Kroll 2018, 224-238.

${ }^{71}$ Iavorskii was inspired by emblem (symbolum) No. 22 and 64 from Saavedra Fajardo's book already in his Echo głosu... For more, see Kroll 2018, 211-242.

72 See Kroll 2018, 228-233. 
vorskii himself: a classical education in Kiev, augmented by studying in Jesuit colleges in Poland and the university in Vilnius, bred a master of acumen and a great emblematist equal to the most important Polish authors of the genre Andrzej Maksymilian Fredro, Jan Gawiński, Stanisław Lubomirski, Zbigniew Morsztyn, and others.

\section{References}

\section{A. Sources}

[Aphthonius] Aphthonii Sophistae Progymnasmata, partim a Rodolpho Agricola, partim a Ioanne Maria Cataneo Latinitate donata, cum luculentis et utilibus in eadem Scholiis Reinhardi Lochichii. (sic!) Hadamarii, Lugduni, Sumptib. Iacobi Carteron, 1640.

[Horatius expurgatus 1613] Quinctus (sic!) Horatius Flaccus, ab omni obscoenitate Romae expurgatus, München, ex typographeo Bergiano, 1613.

[Horatius expurgatus 1652] Quinctus (sic!) Horatius Flaccus, ab omni obscoenitate Romae expurgatus. In usum Gymnasiorum Societatis Iesu, Dilingen, Formis Academicis, 1652.

Jaworski S. Arctos caeli Rossiaci in gentilitiis syderibus Illustrissimi ac Reverendissimi Patris, Patris Barlaami Iasinski, (...) Kijoviensis Halicensis etc. Orthodoxi Archiepiscopi Metropolitae, ad auspicatissimum eius solennique apotheosi celebratum ingressum in Cathedram Metropolitanam Kijoviensem intra communem Orbis Roxolani laetitiam sereno vultu resplendens. Kiev, 1690.

Jaworski S. Hercules post Atlantem infracto virtutum robore honorarium pondus sustinens seu Perillustris et admodum Reverendus Pater, Pater Barlaam Iasinski, Vicarois sedis Metropolitane Kijoviensis (...), post Fata Perillustris ac admodum Reverendi Patris, Patris Innocentii Giziel, Archimandritae Pieczariensis, emeritum eiusdem Archimandriae munus cum festivo omnium applausu subiens. Chernihiv, w Drukarni Świętotrojaieckiej Ilińskiej, 1684.

Jaworski S. Petnia nieubywaiacey chwaty $w$ herbowym xiężycu $z$ trzech primae magnitudinis lumiarzow, Barłaama Swiętego Pustelnika, Barłaama Swiętego Męczenniak, Barłaama Swiętego Pieczarskiego, iednegoż dnia nowrbra 19. Na niebie cerkiewnym swiecacych (...) Barłaamowi Iasinskiemu, Prawosławnemu Archiepiskopowi Metropolicie Kijowskiemu Halickiemu y Wszystkiey Rossiey (...) perezentowana. Kiev, 1691.

\section{B. Secondary literature}

Awianowicz B. Progymnasmata $w$ teorii i praktyce szkoły humanistycznej od końca XV wieku do połowy XVIII wieku. Dzieje nowożytnej recepcji Aftoniosa od Rudolfa Agricoli do Johanna Christopha Gottscheda, Toruń, Wydawnictwa Naukowe UMK, 2008.

Awianowicz B. Die Progymnasmata-Sammlungen und der Glaubenskampf des 17. Jahrhunderts, in: U. Heinen (ed.) Welche Antike? Konkurrierende Rezeptionen des Altertums im Barock, I. Wiesbaden, Harrassowitz Verlag, 2011, 477-489.

Bennett C. E. (ed., transl.). Horace. Odes and Epodes. Cambridge, MA — London, Harvard University Press, 1968.

Brogi Bercoff G. Constructing Canons: Ruthenian Literature of the $17^{\text {th }}-18^{\text {th }}$ Centuries in Plurilingual Context, in: M. Garzaniti et al. (eds). Contributi Italiani al XV Congresso Internazionale degli Slavisti, Firenze University Press, 249-272.

Brogi Bercoff G. Wybory językowe, tożsamościowe i religijne pisarzy ruskich w Rzeczpospolitej XVII-XVIII w., in: W. Walczak, K. Łopatecki (eds). Stan badań nad wielokulturowym dziedzictwem dawnej Rzeczypospolitej, VI. Białystok, Instytut Badań nad Dziedzictwem Kultorowym Europy, 2013, 497-513.

Brogi Bercoff G. Plurilinguism and Identity: Rethinking Ukrainian Literature of the Seventeenth Century Ukraine and Europe, in: G. Brogi Bercoff, M. Pavlyshyn, S. Plokhy (eds). Ukraine and Europe. Cultural Encounters and Negotiations. Toronto, Toronto University Press, 2017, 45-71.

Crinitus P. Cl(audii) Claudiani Poetae Celeberrimi Opera, quorum catalogum, post eius vitam ex Petro Crinito $a c$ 
Demandt A. Novus Hercules - Novus Alexander. Das politische Rollenspiel in der Antike, in: H. Piegeler, I. Prohl, S. Rademacher (ed.) Gelebte Religionen. Festschritft für Hartmut Zinser. Würzburg, Königshausen \& Neumann, 2004, 81-96.

Fedotova M. A. The Epistolary heritage of Dmitry Rostovsky: Studies and Texts. Moscow, Indrik, 2005 (In Russian)

Ficino M. Divini Platonis opera omnia quae exstant. Marsilio Ficino interprete. Frankfut am Mein, Claudius Marnius et haeredes Ioannis Aubrii, 1602.

Ficino M. Platonic Theology. Vol. I: books I-IV. English translation by M. J. B. Allen with J. Warden. Latin text edited by J. Hankins with W. Bowen. Cambridge, MA — London, The I Tatti Renaissance Library, 2001.

Golt G. Oestrium poeticum ephemericum quod ad Davidis citharam excitavit ac quotidianis Dei laudibus consecravit... München, Johann Lucas Straubius, 1712.

Grendler P. F. Jesuit Schools and Universities in Europe 1548-1773. Leiden - Boston, Brill, 2019.

Jabłonowski A. Akademia Kijowsko-Mohilańska. Zarys historyczny na tle rozwoju ogólnego cywilizacyi zachodniej na Rusi. Cracow, Drukarnia A. L. Anczyca i Sp., 1899-1900.

Kapp V. Argutia-Bewegung, in: G. Ueding (ed.) Historisches Wörterbuch der Rhetorik, 1. Tübingen, Max Niemeyer Verlag, 1992, 991-998.

Kraus M. Progymnasmata, Gymnasmata, in: G. Ueding (ed.) Historisches Wörterbuch der Rhetorik, 7. Tübingen, Max Niemeyer Verlag, 2005, 159-190.

Kroll W. “Poeta laureatus” Stefan Jaworski i embleatyka. Terminus 2018, 20,2 (47), 195-253.

Kwiatkiewicz J. Svada civilis oratoriae atque politiae nostratis ingenio accomodata, ut et Phoenix rhetorum, in quo fundamenta necessaria et species rarioris eloquentiae ostenduntur... Wrocław, Johann Adam Kästner, [1679?].

Kwiatkiewicz J. Phoenix rhetorum seu rarioris Atticisimi, nec vulgaris eloquentiae fundamenta in usum oratorum proposita. Prague, Typis Academicis in Coll(egio) S(ocietatis) I(esu), 1690.

Lambin D. Q. Horatius Flaccus: nuper ex fide et auctoritate multorum codicum manu scriptorum opera Dionys(ii) Lambini Monstroliensis emendatus et commentariis illustratus... Antwerp, Ioannes Bellerus, 1584 .

Łużny R. Pisarze kręgu Akademii Kijowsko-Mohylańskiej a literatura polska. Z dziejów związków kulturalnych polsko-wschodniosłowiańskich w XVII-XVIII w. Kraków, Uniwersytet Jagielloński, 1966.

Masen J. Ars nova argutiarum eruditae et honostae recreationis, in duas partes divisa. Prima est epigrammatum, altera inscriptionum argutarum. Köln, Joann Anton Kinckius, 1660.

Maslov S. I. Stefan Yavorsky's Library. Kiev, 1914. (In Russian)

Minell, J., Rappolt F.: Quintus Horatius Flaccus cum notis marginalibus Johannis Minellii et D(omini) Friderici Rappolti [...] commentario [...], nec non Joachimi Felleri [...] supplemento... Leipzig, Christophorus Uhmann, 1675.

Morosov A. A. Metaphor and allegory by Stefan Yavorsky, in: Poetics and stylistics of Russian literature. In memory of academician V. V. Vinogradov. Leningrad, 1971. (In Russian)

Niedźwiedź J. Nieśmiertelne teatra sławy. Kraków, Książnica Akademicka, 2003.

Niedźwiedź J. Jesuit Education in the Polish-Lithuanian Commonwealth (1565-1773). Journal of Jesuit Studies 2018, 5, 441-455.

Nikolaev S. Stefan Iavorsky (1658-1722), in: M. C. Levitt (ed.) Early Modern Russian Writers, Late Seventeenth and Eighteenth Centuries. Detroit - Washington, D. C. - London, A Bruccoli Clark Laymon Book, 1995, 116-119.

Patillon M. (ét., trad.). Corpus rhetoricum. Anonyme, Préambule à la rhétorique, Apththonios, Progymnasmata. Paris, Les Belles Lettres, 2008.

Pelc J. Stowo i obraz. Na pograniczu literatury i sztuk pięknych. Kraków, Universitas, 2002.

Picinelli F. Mondo simbolico formato d'imprese scelte, spiegate ed illustrate con sentenze, ed eruditioni, Sacre, e Profane... dell' Abbate D(omino) Filippo Picinelli Milanese... Milan, Nella Stampa di Francesco Vigone, 1680.

Picinelli, F.: Mundus symbolicus, in emblematum universitate formatus, explicatus et tam sacris quam profanis eruditionibus ac sententiis illustratus..., vol. 1, Cologne, Sumptibus Hemranni Demen, sub signo Monocerotis, 1681

Platnauer M. (ed., transl.) Claudian in Two Volumes. London - New York, 1922.

Poelmann Th. Cl(audius) Claudianus Theod(ori) Pulmanni Craneburgii diligentia et fide summa e vetustis codicibus restitutus. Antwerp, Christophorus Plantinus, 1571. 
Poelmann Th., Delrío M. A. Cl(audius) Claudianus Theod(ori) Pulmanni Graneburgii diligentia et fide summa e vetustis codicibus restitutus et Martini Antonii Del-Rio notis illustratus. Cologne, Petrus de la Rouiere, 1612.

Pontanus J. In P. Ovidii Nasonis poetarum ingeniosissimi Tristium et De Ponto libros novi commentarii, item Hortuli Ovidiani, id est Sententiae et proverbia ex quotquot Poetae monumentis a eodem conquisita in locos communes redacta et commentationibus explicata. Ingolstadt, Adam Sartorius, 1610.

Saavedra Fajardo Diego de. Idea Principis Christiano-Politici 101 Symbolis expressa. Amsterdam, Iodocus Pluymer, 1660.

Sarbiewski M.K. Wykłady poetyki (Praecepta poetica), in: S. Skimina (ed.) Biblioteka Pisarzów Polskich, ser. B, no. 5. Wrocław, 1958.

Shackleton Bailey D. R. (ed.). Q. Horatius Flaccus. Opera. Stuttgart, Teubner, 1985.

Siedina G. The Teaching of Lyric Meters and the Reception of Horace in Kyiv-Mohylanian Poetics, in: G. Siednia (ed.) "Latinitas" in the Polish Crown and the Grand Duchy of Lithuania. Its Impact on the Development of Identities. Firenze University Press, 2014, 99-130.

Siedina G. Horace in the Kyiv Mohylanian Poetics (1 $7^{\text {th }}-$ First Half of the $18^{\text {th }}$ Century): Poetic Theory, Metrics, Lyric Poetry. Firenze University Press, 2017.

Słomak I. "Phoenix rhetorum" Jana Kwiatkiewicza. Wprowadzenie - przekład - opracowanie. Warszawa, Wydział Polonistyki UW, 2016.

Ternovskii F. A. Essays from the history of the Russian hierarchy in the $18^{\text {th }}$ century. Stefan Yavorsky. Drevniaia i novaia Rossiia, 1879, 8, 305-320.

Treadgold D. W. The West in Russia and China. Religious and Secular Thought in Modern Times. Vol. 1: Russia, 1472-1917. Cambridge, 1973.

Zakhara I.S. Stefan Yavorsky. L'viv, Kameniar, 1991.

Received: March 3, 2020

Accepted: June 27, 2020 